\title{
Wykorzystanie metody person w projektowaniu usług bibliotek szkół wyższych ${ }^{1}$
}

\author{
Jakub Opas \\ Cheil Poland
}

\begin{abstract}
Abstrakt
Cel/Teza: Celem artykułu jest przedstawienie nowego podejścia do identyfikacji potrzeb użytkowników bibliotek na podstawie tzw. metody person.

Koncepcja/Metody badań: Podstawą artykułu jest analiza piśmiennictwa przedmiotu oraz materiałów źródłowych uzyskanych od pracownika biblioteki Högskolan i Borås (Szkoły Wyższej w Borås). Wykorzystanie metody person w projektowaniu usług bibliotecznych przedstawiono na przykładzie czterech studiów przypadków: Biblioteki Högskolan i Borås (Szwecja), bibliotek wydziałowych Uniwersytetu Kolorado w Boulder (USA), Biblioteki Uniwersytetu Cornella w Ithace (USA), Biblioteki Uniwersytetu Macquarie w Sydney (Australia).

Wyniki i wnioski: Scharakteryzowano metodę wypracowaną na gruncie pola naukowego komunikacji człowiek-komputer. Analiza przykładów opisanych w niniejszym artykule potwierdziła, iż wykorzystanie w badaniu potrzeb użytkowników nowych metod wypracowanych w innych naukach może zaowocować zapewnieniem większej funkcjonalności placówek bibliotecznych i lepszym dopasowaniem ich usług do potrzeb użytkowników.

Oryginalność/Wartość poznawcza: W artykule zaproponowano nowe podejście do identyfikacji potrzeb użytkowników, jak dotąd nie obecne w polskiej literaturze przedmiotu.
\end{abstract}

\section{Słowa kluczowe}

Biblioteki szkół wyższych. Badania użytkowników. Metoda person. Profile użytkowników. Użytkownicy informacji.

Otrzymany: 18 lipca 2016. Zrecenzowany: 9 grudnia 2016. Poprawiony: 13 stycznia 2017.

Zaakceptowany: 31 stycznia 2017.

\section{Wprowadzenie}

W dobie szybkiego rozwoju technologicznego oczekiwania użytkowników bibliotek ulegają daleko idącym zmianom. Bibliotekarze, dążąc do coraz lepszego poznania użytkowników swoich bibliotek, sięgają po metody wypracowane w innych dziedzinach naukowych.

Drogą do lepszego dostosowania usług bibliotecznych do potrzeb i oczekiwań użytkowników może być pogłębione badanie potrzeb i zachowań użytkowników z wykorzystaniem metody sprawdzonej m.in. w tzw. projektowaniu systemów informacyjnych

1 Artykuł został opracowany na podstawie pracy licencjackiej pt. Współczesne profile użytkowników biblioteki akademickiej na przykładzie biblioteki w szwedzkiej miejscowości Borås, napisanej pod kierunkiem dr Teresy Święćkowskiej, obronionej we wrześniu 2013 r. na kierunku informacja naukowa i bibliotekoznawstwo na Uniwersytecie Warszawskim. 
ukierunkowanych na użytkownika. W artykule przedstawiono na przykładzie czterech studiów przypadków wykorzystanie tzw. metody person do modelowania potrzeb użytkowników bibliotek akademickich. Metodologia ta według wiedzy autora nie była dotychczas stosowana w polskich badaniach bibliologiczno-informatologicznych. Tym samym, materiał badawczy wykorzystany w artykule pochodzi z piśmiennictwa anglojęzycznego.

\section{Metoda person}

Słowo persona pochodzi z języka łacińskiego i ma trzy znaczenia: odnosi się do maski noszonej przez aktora w antycznym teatrze greckim, określa odgrywaną na scenie rolę, lub rozumiane dosłownie oznacza konkretną osobę - człowieka (Plezia, 1999, 129-130). W psychologii termin ten definiowany jest jako „maska” odzwierciedlająca rolę odgrywaną w otaczającym człowieka środowisku (Leeming et al., eds., 2010, 670-672).

Współcześnie, w badaniach z obszaru interakcji człowiek-komputer (ang. Human-computer interaction) słowo persona nabrało nowego znaczenia za sprawą amerykańskiego programisty Alana Coopera (Chang et al., 2008, 439). W świecie programistycznym nazywany jest on „ojcem” języka Visual Basic, a zawodowo zajmuje się ukierunkowanym na użytkownika projektowaniem cyfrowych usług i produktów (Cooper Interaction Design, 1996; Cooper, 2013). Już w latach 90. XX w., bazując na nabytych wcześniej doświadczeniach, Cooper postanowił zrewolucjonizować ówcześnie funkcjonujący proces projektowania oprogramowania. Uważał, że zbyt mało uwagi poświęca się projektowaniu produktu, na pierwszym planie stawiając jego wyprodukowanie (Cooper, 2004, 14-16). Autorskie koncepcje, wskazujące drogę do lepszego projektowania, przedstawił w książce zatytułowanej The Inmates Are Running the Asylum (Cooper, 2004).

Jednym z rozwiązań usprawniających pracę nad projektem, które zaproponował Cooper jest koncepcja person, rozumiana jako „hipotetyczny archetyp rzeczywistego użytkownika" (Cooper, 2004, 124). Innymi słowy, jest to drobiazgowy opis użytkownika, dla którego powstaje projektowany produkt. Ów opis, łączy w sobie wymyślone szczegóły osobowości (imię, nazwisko, miejsce zamieszkania, przeszłość itd.) z celami, do których dana osoba dąży. Taka charakterystyka musi być zbudowana na podstawie wyników przeprowadzonych wcześniej badań i dodatkowo może zostać zwizualizowana za pomocą obrazu (np. fotografii) - wszystko, w celu zarysowania postaci, w której istnienie można łatwo uwierzyć (Cooper, 2004, 123-124).

Ważnym elementem tworzenia fikcyjnych osobowości jest dbałość o szczegóły (Cooper, 2004, 128). Przykładowo stwierdzenie - „Agata jeździ do pracy samochodem”, nie przekłada się na urealnienie wizerunku persony nazwanej Agatą. Jednak w momencie dodania do poprzedniego zdania informacji, np. że prowadzi samochód Toyota (rocznik 2014), na tylnym siedzeniu wozi fotelik dla dzieci i co więcej - pracuje jako kierowniczka biblioteki publicznej w Wilanowie w Warszawie, to zdaniem Coopera $(2004,128)$ dana persona staje się znacznie bardziej realna w umysłach projektantów i programistów.

Nie można jednak wykorzystać do wykreowania persony dokładnego opisu zachowań prawdziwej osoby (Cooper, 2004, 129). Wynika to z faktu, iż prawdziwi użytkownicy cechują się czasem nietypowymi zachowaniami, które są charakterystyczne tylko i wyłącznie dla nich. Uwzględnianie takich zachowań w procesie projektowania mija się z celem, ponieważ 
niemożliwe jest wzięcie pod uwagę każdej anomalii. Dobrą ilustracją tego problemu jest podany przez Coopera $(2004,129)$ przykład:

Załóżmy, że dyrektor przedsiębiorstwa (który nienawidzi pracy z komputerem na klawiaturze) zarządzil, że w całej firmie komputery będą obsługiwane tylko za pomocą myszki. Utrudniłby on tym samym pracę wszystkim pracownikom, którzy korzystanie z klawiatury uważają za wygodniejsze.

Osoba przywołanego dyrektora, z powodu swojego specyficznego podejścia do obsługi komputera, nie byłaby zatem dobrą personą.

Twórcom fikcyjnych osobowości dążenie do precyzji ich opisu nie może przesłonić trafność charakterystyki wybranego użytkownika. Inaczej, projektowany program można uznać za poprawnie działający - nawet przy niewielkich wewnętrznych „tarciach” - pod warunkiem, że wykonuje on zaplanowaną przez projektantów czynność lub serię czynności (Cooper, 2004, 129). Analogiczne rozumowanie odnosi się do kreowanej persony. Ważniejsze jest, aby była ona wyrażona z wystarczającą precyzją (dostateczną dla potrzeb projektu), niż żeby była to idealnie trafna charakterystyka pewnej osobowości. Należy przy tym powstrzymać się od uśredniania charakteryzowanych osobowości (Cooper, 2004, 130).

Według Coopera $(2004,131-135)$ optymalna liczba person opracowywanych dla jednego projektu mieści się w granicach od trzech do 12 unikalnych osobowości (ze względu na tę unikalność poszczególne osobowości są użyteczne tylko dla konkretnego projektu). Jako przykład tej prawidłowości Cooper przytacza projekt tworzony dla potrzeb oddziału firmy Sony zajmującego się przygotowaniem interfejsu graficznego systemu multimedialnego wykorzystywanego w samolotach pasażerskich (Cooper, 2004, 142). Początkowo liczba person dla tego projektu wyniosła aż 30. Następnie, wraz z coraz lepszym poznawaniem specyfiki projektu oraz użytkowników, do których skierowany miał być produkt, możliwe było połączenie kilku osobowości o podobnych celach w jedną i ograniczenie tym samym liczby person do 10 (czterech pasażerów oraz sześciu osób z obsługi samolotu). Cooper zwraca uwagę, iż projektowanie za pomocą metody person nie zakłada wykorzystania w implementacji wszystkich stworzonych osobowości. W niektórych przypadkach mogą one ilustrować takie wzorce użytkowników, dla jakich produkt nie jest projektowany (Cooper, 2004, 135).

Cooper zaleca projektowanie produktu czy usługi dla określonej, pojedynczej osoby, a nie szerszego kręgu użytkowników. Uzasadnia ten pomysł przywołując następującą anegdotę:

Projektant ma za zadanie stworzyć samochód spełniający wymogi trzech przykładowych postaci: matki młodych sportowców, stolarza oraz młodego kierownika. Kombinacja trzech zupełnie różnych koncepcji zaowocowałaby furgonetką z otwieranym dachem, obszernym wnętrzem dla dzieci oraz otwartą przestrzenią załadunkową na drewno, narzędzia i drabiny. O ile dałoby się coś takiego stworzyć, najprawdopodobniej i tak nikt by tego nie kupił. Zamiast tego, matka wybrałaby małego vana, stolarz samochód półciężarowy a kierownik samochód sportowy (Cooper, 2004, 124-125).

Można by sądzić, iż rozbudowany i wielofunkcyjny produkt ma większe szanse zaspokoić potrzeby szerszego kręgu użytkowników. Tymczasem Cooper, posiłkując się nabytym doświadczeniem przekonuje, iż kluczem do sukcesu - dotarcia do jak najszerszej grupy odbiorców - jest (sprzecznie z intuicją) projektowanie dla pojedynczego użytkownika (Cooper, 2004, 125). 


\section{Rodzaje person}

Pomysł Alana Coopera wzbudził zainteresowanie w świecie projektantów interakcji ${ }^{2}$. Przytoczone w Tab. 1 zestawienie pokazuje różne modyfikacje i warianty metody person, zaproponowane w piśmiennictwie przedmiotu (Floyd et al., 2008). Autorzy zestawienia wyróżnili siedem najważniejszych typów podejścia do tworzenia person. Dwa pierwsze typy person („wstępna” oraz „ostateczna”) odnoszą się do pomysłu zaproponowanego przez Alana Coopera. Utworzenie dużej liczby „wstępnych” person, opartych na badaniach oraz danych etnograficznych, pozwala na uchwycenie charakterystycznych cech badanych użytkowników. Późniejsze poszukiwanie cech wspólnych stworzonych osobowości prowadzi do odkrycia mniejszego zbioru person "ostatecznych” z reguły wykorzystywanych tylko do końca trwania danego projektu (Floyd et al., 2008, 4).

Persony w rozumieniu Pruitta i Grudina (2003, 2-3) są zmodyfikowaną koncepcją Coopera. Ich projektowanie jest silnie osadzone w danych pozyskiwanych zarówno z badań ilościowych jak i jakościowych. Brak procesu scalania daje w efekcie dziesiątki person, które mogą być wykorzystywane wielokrotnie, również przy innych projektach (Floyd et al., 2008, 4-5).

Podejście do tworzenia fikcyjnych osobowości oparte na korzystaniu głównie z danych ilościowych przedstawia Sinha $(2003,830)$. Badaczka ta proponuje szukanie zgrupowań obecnych w analizowanych wynikach ankiet, a następnie kreowanie person dla każdego odkrytego zgrupowania. Zdaniem Floyd et al. $(2008,5)$ branie pod uwagę tylko danych ilościowych może budzić wątpliwości co do kompletności odwzorowania cech istotnych dla użytkowników.

Kolejne podejście do tworzenia person, w przeciwieństwie do przytoczonych powyżej, bazuje przede wszystkim na wyobraźni projektanta. Persony „Ad-Hoc” są wymyślane bez dużej dozy szczegółowości i oparcia na wynikach przeprowadzonych badań. Kreowane są niemal "na poczekaniu” i mają na celu wzbudzenie empatii wobec person tworzonych w procesie projektowania produktu (Norman, 2004).

Archetypy użytkowników cechują się większym od person stopniem ogólności. Podczas gdy fikcyjna osobowość ma za zadanie scharakteryzować pojedynczego użytkownika, archetyp jest bardziej elastyczny - pozwala na opisanie całej grupy użytkowników, np. „podróżujący biznesmen” czy „administrator”. Korzystanie z archetypów może prowadzić do uzyskania wieloaspektowego, rozmytego wyobrażenia użytkownika, czyli dokładnego przeciwieństwa idei person (Floyd et al., 2008, 5).

Ostatni wymieniony typ to persony budowane dla potrzeb marketingowych. Choć mogą one zawierać dane przydatne przy tworzeniu innych rodzajów fikcyjnych osobowości, stricte reklamowe nastawienie opisywanych person zdecydowanie ogranicza ich użyteczność dla celów projektowania np. oprogramowania (Floyd et al., 2008, 5). Dla pełniejszego oddania różnorodności krajobrazu person, warto przytoczyć jeszcze trzy koncepcje.

\footnotetext{
2 Projektowanie interakcji - dyscyplina zajmująca się „definiowaniem struktury i zachowania systemów interaktywnych. Projektanci interakcji dążą do stworzenia istotnych relacji między ludźmi i produktami oraz usługami, z których korzystają, od komputerów i mobilnych urządzeń poczynając, poprzez inne urządzenia i poza nie" (Interaction Design Association: IxDA Mission, 2014).
} 


\begin{tabular}{|c|c|c|c|c|}
\hline 㣢 & $\infty$ & 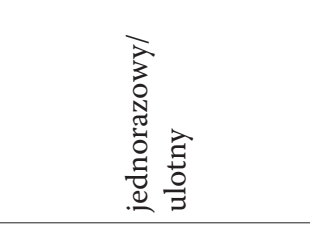 & 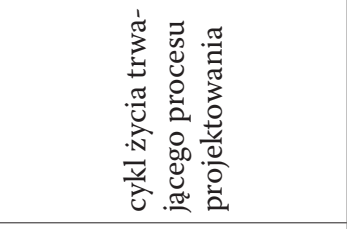 & 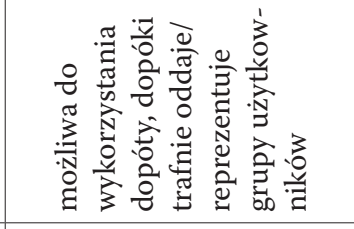 \\
\hline 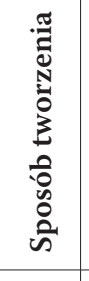 & $\wedge$ & 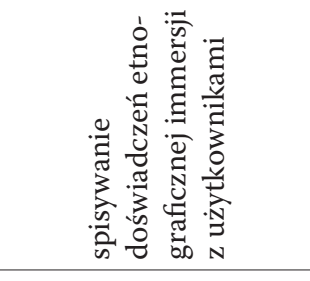 & 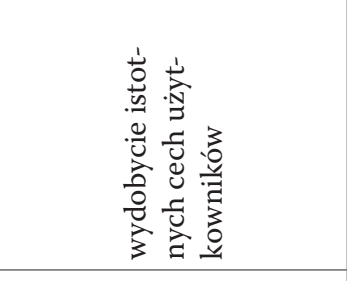 & 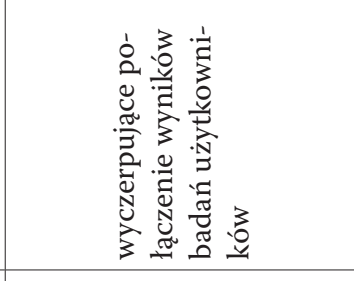 \\
\hline 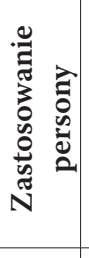 & 6 & 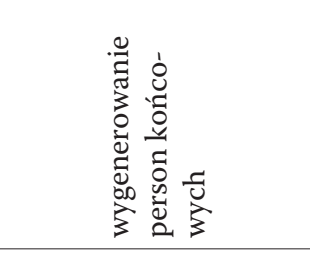 & 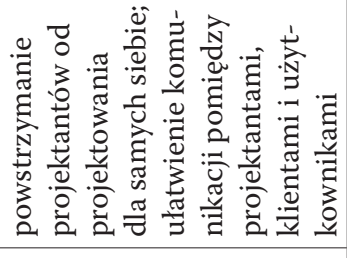 & 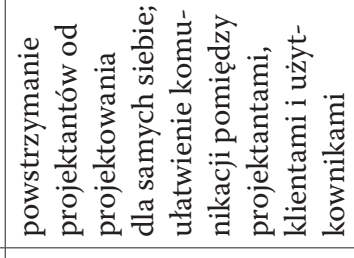 \\
\hline 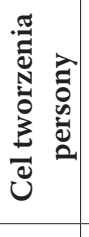 & & 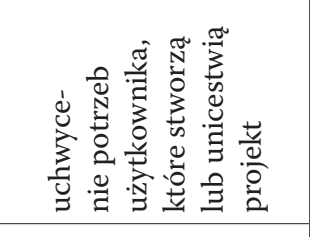 & 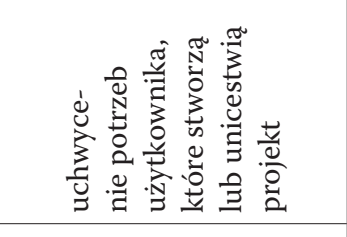 & 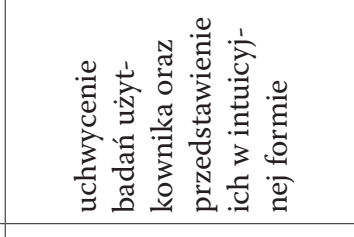 \\
\hline 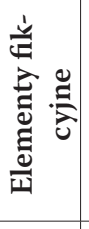 & & 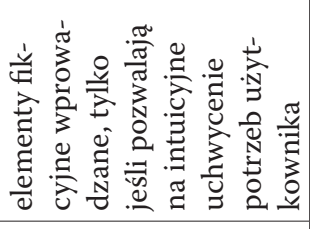 & 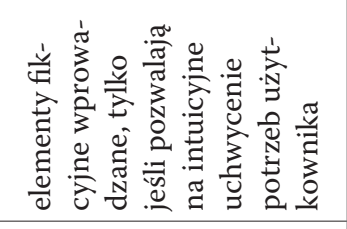 & 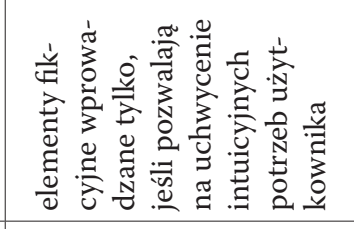 \\
\hline 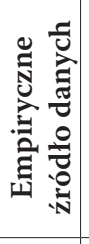 & & 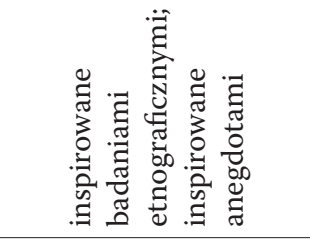 & 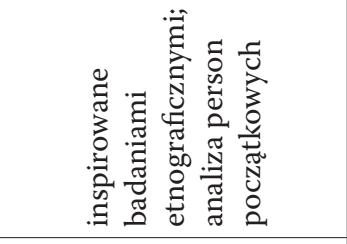 & 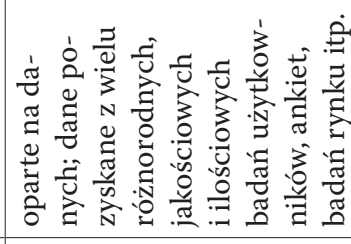 \\
\hline 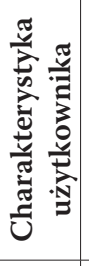 & & 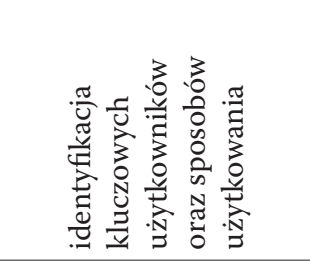 & 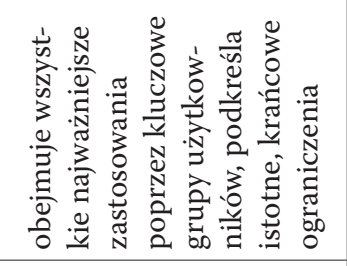 & 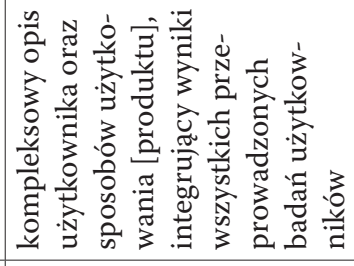 \\
\hline 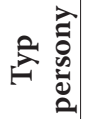 & & 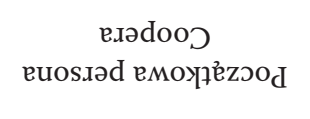 & 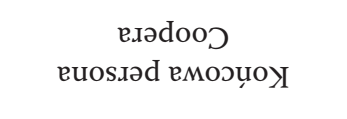 & 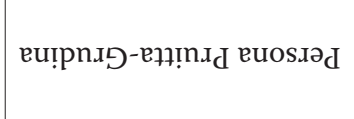 \\
\hline
\end{tabular}




\begin{tabular}{|c|c|c|c|c|}
\hline$\infty$ & 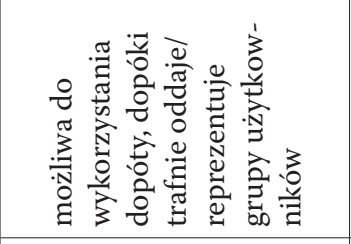 & 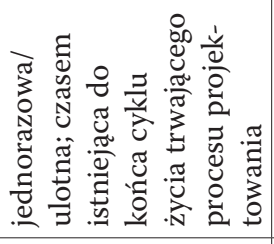 & 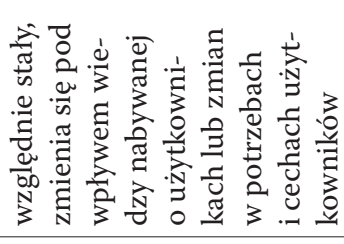 & 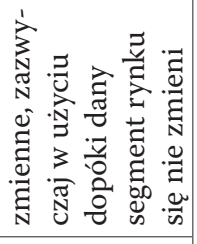 \\
\hline$\Lambda$ & 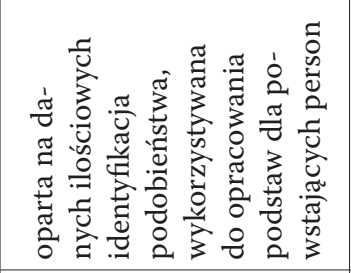 & 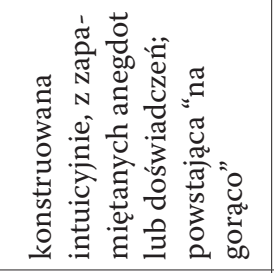 & 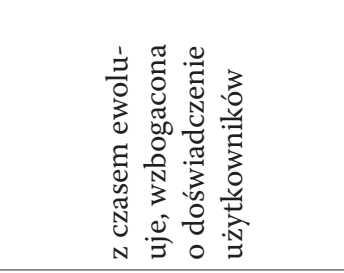 & 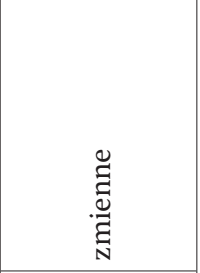 \\
\hline$\bullet$ & 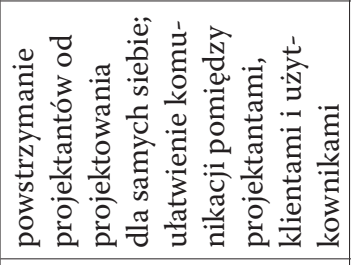 & 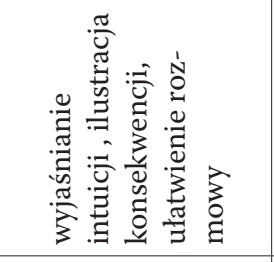 & 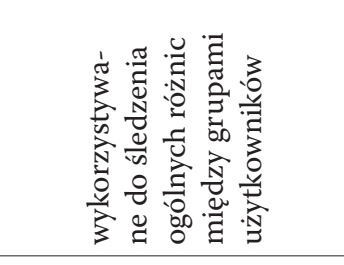 & 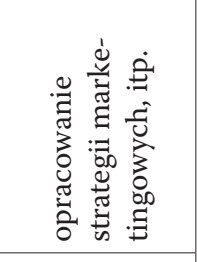 \\
\hline in & 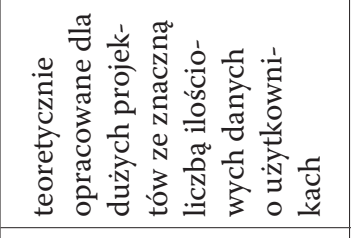 & 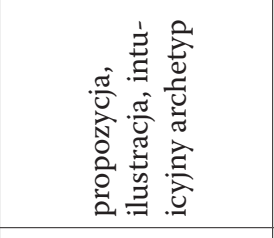 & 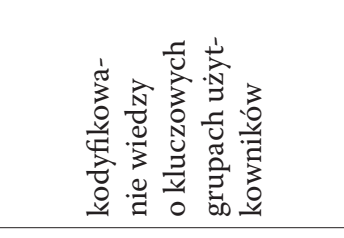 & 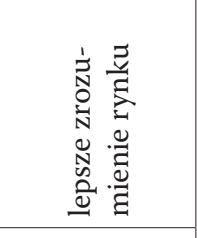 \\
\hline A & 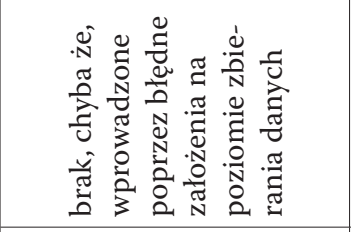 & 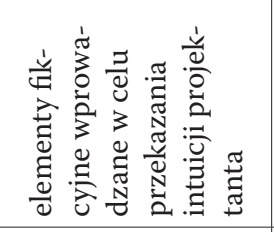 & 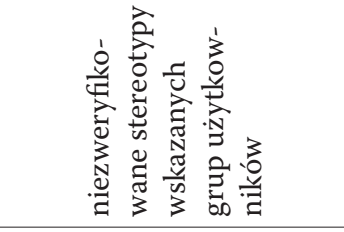 & 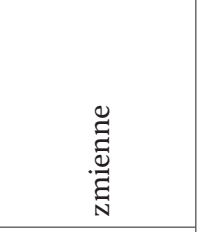 \\
\hline$m$ & 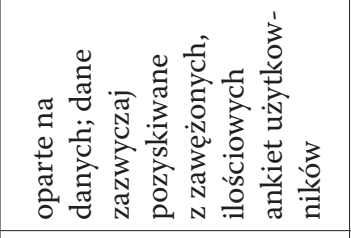 & 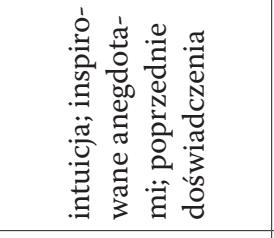 & 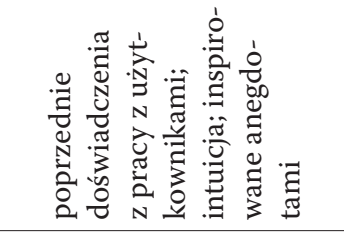 & 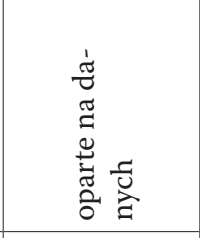 \\
\hline$N$ & 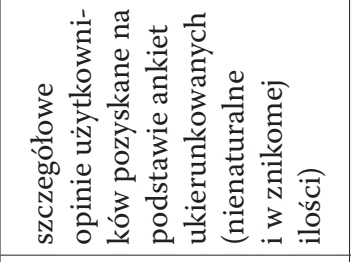 & 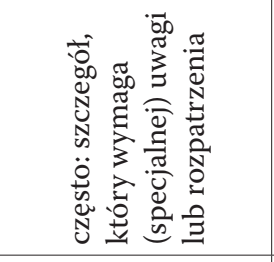 & 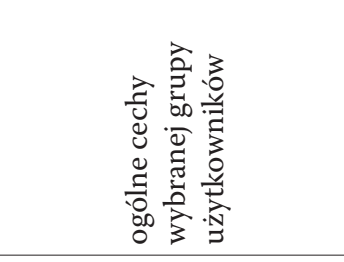 & 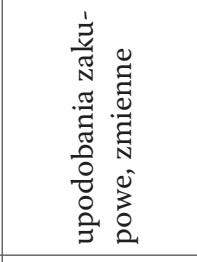 \\
\hline-1 & Кчu!S еuosıəd & 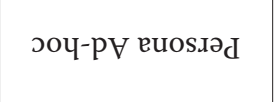 & 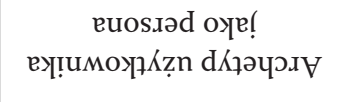 & $\begin{array}{c}\text { емовичฺฺәу } \\
\text {-леш еuоsıәд }\end{array}$ \\
\hline
\end{tabular}


Jedno z podejść odmiennych wobec opisywanej wcześniej koncepcji Alana Coopera, powstało na gruncie krytyki niektórych jego założeń dotyczących person oraz tradycyjnego podejścia do projektowania systemów ${ }^{3}$. Zwrócono w nim uwagę między innymi na wykorzystanie po równo ilościowych, jak i jakościowych materiałów w trakcie konstruowania person, a także potrzebę jasnego zdefiniowania relacji zachodzącej między zebranymi danymi i powstającymi osobowościami. Podważono wizję person, jako metody samodzielnej, tzn. zastępującej inne metody oraz zakwestionowano nadawanie zbyt małego znaczenia idei zaangażowania użytkownika. Zaznaczono także, iż opis charakteryzujący personę powinien sugerować jakie posiada ona kompetencje informacyjne oraz jakie ma nadzieje i obawy. Powinien uwzględniać również wiedzę o wpływie, jaki wywiera na nią rynek i jak dużą jego część reprezentuje oraz krótki opis typowego dnia lub tygodnia z jej życia. Perspektywa obejmująca rozważane powyżej kwestie nazywana bywa podejściem opartym na odgrywanej roli (Nielsen, 2013, 15).

Innym ujęciem rozważanej metody jest spojrzenie promowane przez Lene Nielsen (2016). Balansując między wiedzą zdobytą w trakcie badań użytkowników a fikcyjnymi szczegółami, Nielsen rozwija ideę tworzenia charakterystyki osobowości włączając w nią umiejętność zaangażowania odbiorcy. Kreowany opis ma umożliwić wyobrażenie i utożsamienie fikcyjnej osobowości z jednym z możliwych lub prawdziwych użytkowników oraz wzbudzić u projektanta empatię. Podkreślenie indywidualizmu jednostki pozwala na walkę z postrzeganiem użytkowników w stereotypowych kategoriach i zarazem umożliwia powstawanie nieszablonowych i kreatywnych pomysłów (Nielsen, 2013, 16).

Intrygującym pomysłem zdaje się być korzystanie ze „skrajnych person” (np. wyimaginowanego handlarza narkotykami, hedonistycznej i poliandrycznej dwudziestolatki, czy... papieża). Według Djajadiningrata, Gavera i Fresa (2000, 66-71) może okazać się ono zupełnie niespodziewaną drogą do pożądanego na rynku świeżego spojrzenia na kreowany produkt.

\section{Metoda person w modelowaniu potrzeb użytkowników bibliotek szkół wyższych - cztery studia przypadków}

Opisana metoda person spotkała się z zainteresowaniem również wśród bibliotekarzy poszukujących sposobów na coraz lepsze poznawanie potrzeb użytkowników swoich bibliotek. To jak została przez nich zastosowana, opisano poniżej na przykładzie czterech bibliotek akademickich.

\footnotetext{
3 Wśród krytyków podejścia Coopera, Lene Nielsen wymienia: Mikkelson \& Lee, Grudin \& Pruitt, Pruitt \& Adlin, Sønderstrup-Andersen (Nielsen, 2013, 15).
} 


\subsection{Biblioteka Szkoty Wyższej w Borås (Szwecja) ${ }^{4}$}

Koncepcja person została wykorzystana przez pracowników biblioteki Szkoły Wyższej w Borås ${ }^{5} \mathrm{w}$ procesie reorganizacji placówki w latach $2010-2011^{6}$. Instytucja ta jako pierwsza w Szwecji stworzyła persony przy okazji wprowadzania zmian w fizycznej organizacji biblioteki.

Pomysł przebudowy placówki pojawił się jako odpowiedź na zaobserwowane zmiany $\mathrm{w}$ wymaganiach stawianych przed biblioteką. Dotyczyły one między innymi nowatorskich form pracy na uczelni, kształtowania się nowych zwyczajów związanych ze studiowaniem, a także szybkiego rozwoju technologicznego. W poszukiwaniu inspiracji do modernizacji, jeden z pracowników biblioteki w Borås, wraz z dziewięcioma innymi skandynawskimi bibliotekarzami został oddelegowany na wyjazd szkoleniowy do Stanów Zjednoczonych. Dostrzeżone przez niego pomysły i innowacje znalazły rozwinięcie w pracy czteroosobowej grupy pracowników: Martina Borga, Klaza Arvidsona, Tove Lekseliusa i Svante Kristenssona. Miała ona na celu zebranie i opracowanie propozycji możliwych zmian dla biblioteki.

Ich pierwszym zadaniem było przejrzenie i uporządkowanie pozyskanych do tego czasu informacji. Rozpoczęli od przeanalizowania opinii przesyłanych przez specjalny formularz na stronie WWW biblioteki - „Wyraź swoją opinię o bibliotece”, odbieranych w ten sposób od 2004 r. Skategoryzowali informacje zawarte w kilku przeprowadzonych ankietach uwzględniających np. pytania: „Co użytkownicy myślą o bibliotece?”, „Czego im w niej brakuje?”, „Co mogłoby zostać rozwiązane lepiej?”. Korzystając z funkcji systemu zliczania odwiedzin w bibliotece, ustalili progi dziennych wizyt oraz pory dnia, w których bibliotekę odwiedza najwięcej osób. Przeglądając gromadzone w systemie statystyki wskazali kategorie studentów najczęściej korzystających z pokojów do pracy grupowej, wypożyczających najwięcej książek oraz najintensywniej użytkujących dostępne w bibliotece stanowiska komputerowe. Wzięli również pod uwagę niektóre dane demograficzne np. wiek, płeć, pochodzenie.

Zebrane w ten sposób dane zostały uzupełnione o informacje pochodzące z kwestionariuszy wywiadów z czytelnikami oraz o uwagi użytkowników pochodzące z uruchomionego na potrzeby projektu bloga internetowego.

Na podstawie zebranych danych, wyodrębnili dziesięć najważniejszych obszarów problemowych:

(1) Cicha czytelnia

(2) Stanowiska komputerowe

(3) Pokoje do pracy grupowej

${ }^{4}$ Ze względu na bogaty materiał źródłowy, pozwalający na dokładniejsze omówienie opisywanej placówki, pierwszemu studium przypadku poświęcone zostanie więcej miejsca, niż następnym przedstawianym bibliotekom.

${ }^{5}$ Library and Learning Resources (LLR) - pełna nazwa biblioteki Szkoły Wyższej w Borås.

${ }^{6}$ Przedstawione $\mathrm{w}$ tym podrozdziale informacje i opinie odnoszą się do wywiadu przeprowadzonego 9 listopada 2012 r. z Martinem Borgiem - pracownikiem biblioteki akademickiej w Borås, zatrudnionym na stanowisku Manager Collection Services.

${ }^{7}$ Projektowanie architektury bibliotecznej skoncentrowanej na użytkowniku podkreśla m.in. Cheryl LaGuardia (1998). 
(4) Miejsca do studiowania

(5) Dział czasopism

(6) Las książek ${ }^{8}$ i półki kompaktowe

(7) Wyposażenie techniczne

(8) Punkt informacyjny / pomoc w szukaniu/ pomoc komputerowa

(9) Wyposażenie do samodzielnego wypożyczania i zwracania książek

(10) Ogólne środowisko pracy: poziom dźwięku, klimat, zakaz spożywania posiłków, itd.

Po zidentyfikowaniu najistotniejszych kwestii przyszła kolej na stworzenie profili użytkowników biblioteki. Proces kształtowania person pod względem merytorycznym i metodologicznym nadzorował Andrea Resmini - wykładowca School of Business and IT tamtejszego uniwersytetu. Konstruowanie fikcyjnych osobowości rozpoczęto od stworzenia grup fokusowych. Sięgając do zebranych materiałów, wyodrębniono początkowo sześć grup: studentki pedagogiki, studentów inżynierii, a także mieszane grupy studentów bibliotekoznawstwa (byli oni także grupą pilotażową projektu), projektantów mody, doktorantów i digital natives ${ }^{9}$. Jednak ze względu na sporadyczną obecność doktorantów w bibliotece oraz trudności ze znalezieniem osób chętnych do wzięcia udziału w badaniu wśród przedstawicieli z ostatniej wymienionej grupy, badacze zrezygnowali z tych dwóch zbiorowości.

Początkowo, zespół starał się zgromadzić uczestników badania poprzez pocztę elektroniczną uniwersyteckiego systemu obsługi studentów, jednak liczba uzyskanych w ten sposób zgłoszeń okazała się zbyt mała (Högskolan i Borås, 2014b). Zachęcano więc użytkowników biblioteki do wzięcia udziału w badaniach w inny sposób - oferując darmowy lunch w zamian za poświęcony czas. Uformowano w ten sposób trzy z czterech planowanych grup fokusowych. W znalezieniu ostatniej grupy pomogła wykładowczyni z Wydziału Tekstyliów, która podpowiedziała gdzie najłatwiej znaleźć skorych do wzięcia udziału w badaniach przyszłych projektantów mody. Po dyskusjach w wytypowanych grupach fokusowych, jak również uwzględnieniu wcześniej pozyskanych informacji, stworzone zostały cztery fikcyjne osobowości: Hedwig, Lisa, Reza i Teresa (zob. Załącznik).

Persona Hedwig to studentka i przyszła projektantka mody. Pochodzi z inteligenckiej rodziny i niedługo skończy 30 lat. Poza ukończonymi kursami teoretycznymi w kraju, przez rok pracowała w wymarzonym zawodzie za granicą, a także ukończyła studia na Akademii Krawieckiej w Kopenhadze. Spośród bibliotecznych zasobów wysoko ceni literaturę o inspirującym charakterze i z chęcią przebywa w relaksującym otoczeniu, np. w przestrzeni wyposażonej w wygodne fotele.

Persona Lisa to osoba obdarzona „humanistyczną duszą”. Studiowała literaturoznawstwo na Uniwersytecie w Göteborgu, jednak zrezygnowała z tej ścieżki kariery na rzecz spełniania się w roli bibliotekarza. Lisa ma 26 lat, często odwiedza bibliotekę i spędza w niej dużo czasu, pracując lub przygotowując na zajęcia. Najchętniej przebywa na czwartym piętrze biblioteki ponieważ jest tam spokojniej, niż na pozostałych poziomach, a poza tym książki $\mathrm{z}$ dziedzin bibliotekoznawstwa i informacji naukowej są na wyciągnięcie ręki. Z uwagi na studiowany kierunek, niezbyt chętnie korzysta z pomocy oferowanej przez bibliotekarzy.

\footnotetext{
8 Określenie używane przez pracowników LLR, odnoszące się do miejsc siedzących, rozlokowanych pomiędzy regałami bądź w wyznaczonych przerwach między nimi, w przeciwieństwie do wolno stojących stolików przy schodach i oknach.

9 Pod tą nazwą rozumie się „osoby urodzone lub wychowane w czasach cyfrowej technologii i z tego powodu, zaznajomione z komputerami i Internetem od lat młodości” (Digital native, 2014).
} 
Reza jest jedynym mężczyzną wśród wykreowanych person. Jest 21-letnim studentem inżynierii i mechaniki. Zaintrygowany techniką i maszynami od najmłodszych lat chciał kontynuować naukę na prestiżowych szwedzkich uczelniach, lecz jego oceny nie spełniły wysokich wymogów rekrutacyjnych i aktualnie studiuje w Högskolan i Borås. Biblioteka jest dla niego dobrym miejscem do wspólnej pracy z kolegami z roku. Bardzo ważną kwestią jest dla niego dostępność do dobrze funkcjonującego wyposażenia technicznego wraz z miejscem do pracy grupowej.

Ostatnia i zarazem najstarsza postać na imię ma Teresa, ma 32 lata i jest studentką drugiego roku studiów pedagogicznych. Jest osobą zakochaną w dzieciach i odkąd sięga pamięcią, praca z najmłodszymi jest dla niej wymarzonym zajęciem, któremu poświęca się całym sercem. W wieku 23 lat urodziła córkę i dlatego dysponuje ograniczoną ilością czasu, którą może przeznaczyć na studia. Postrzega bibliotekę, jako wygodne miejsce do pracy grupowej i gdyby istniała możliwość zjedzenia czegoś w bibliotecznych lokalach, to chętnie uniknęłaby przerywania pracy i wychodzenia na zewnątrz.

Wykreowane persony zostały skonfrontowane z dziesięcioma wyróżnionymi wcześniej obszarami tematycznymi. Jako przykład ich funkcjonalności, Martin Borg przytoczył częściowe omówienie jednej z rozważanych kwestii - cichej czytelni. Hedwig ze względu na swój styl nauki (praca grupowa lub w pokojach dostępnych na Wydziale Tekstyliów) nie potrzebowała w ogóle takiego miejsca. Z drugiej strony, Lisa była zdania, że w bibliotece powinna znajdować się cicha czytelnia nawet, jeśli mało osób z niej korzysta. Reza i Teresa przywiązywali po równo niewielkie znaczenie do obecności takiego pomieszczenia w bibliotece. Do zarysowywanego obrazu dołączono komentarze zamieszczone na blogu, które zgodnie opowiadały się za istnieniem cichej czytelni. Pod uwagę wzięto również wyniki przeprowadzonych badań ankietowych - $29 \%$ spośród 542 respondentów odpowiedziało, że często lub czasami korzysta z czytelni, a 6\% badanych nie wiedziało nawet o jej istnieniu. Dodano również opinie zebrane za pośrednictwem formularza umieszczonego na stronie WWW biblioteki, odnoszące się do temperatury i poziomu hałasu. W końcowych wnioskach zespół badawczy podkreślił, iż lokal czytelni jest zbyt duży lub nie w pełni wykorzystywany. Zasugerowano zmniejszenie pomieszczenia czytelni o połowę zajmowanej dotychczas powierzchni, lub jego podział na dwie części: cichą czytelnię oraz cichą pracownię komputerową.

W efekcie przeprowadzonych badań, biblioteka uległa znaczącym zmianom. Całkowicie zreorganizowano przestrzeń parteru - półki z książkami przemieszczono na sąsiednie piętra, zastępując je przestrzenią nasuwającą na myśl miejsce przeznaczone do odpoczynku: z wygodnymi kanapami i fotelami oraz lampkami do oświetlenia czytanej lektury. W sąsiedztwie wejścia umieszczono stanowiska obsługiwane przez dyżurujących bibliotekarzy, połączone z ofertą usług pomocy przy wyszukiwaniu informacji. Równocześnie z opisanymi zmianami w życie wcielono planowane wcześniej modernizacje, w tym doposażono wszystkie książki o chipy RFID, przygotowując tym samym grunt pod zakup bezobsługowych stacji wypożyczających oraz instalację automatycznego systemu zwrotu. Wdrożono również nowoczesny system wyszukiwawczy typu discovery - Summon, oferowany przez firmę Serial Solutions (Serials Solutions, 2012). Pozwala on na równoczesne przeszukiwanie zarówno materiałów drukowanych, jak i dostępnych e-zbiorów, czy administrowanych przez uniwersytet baz danych (np. BADA) (Högskolan i Borås, 2014a). 


\subsection{Biblioteki wydziatowe Uniwersytetu Kolorado w Boulder (USA)}

Metoda person znalazła także zastosowanie w badaniu przeprowadzonym przez troje kierowników wydziałowych bibliotek Uniwersytetu Kolorado (Lage et al., 2011). Analizie poddana została działalność biblioteki akademickiej związana z długoterminowym przechowywaniem danych (ang. data curation). Badanie miało na celu odkrycie potrzeb naukowców, a także ocenę współpracy bibliotek akademickich z naukowcami w zakresie długoterminowego przechowywania danych, ze szczególnym uwzględnieniem:

rodzajów tworzonych zbiorów danych, już istniejących zasobów oraz oferowanego przez bibliotekę wsparcia, kultury badawczej rozwiniętej w różnych dyscyplinach lub własnych odczuć związanych z dzieleniem się zasobami, a także odbiorem roli odgrywanej przez bibliotekę w procesie długoterminowego przechowywania danych (Lage et al., 2011, 916).

Na potrzeby projektu przeprowadzono serię godzinnych wywiadów z 26 naukowcami reprezentującymi szeroki zakres pól naukowych - od inżynierii kosmicznej poprzez chemię organiczną i klimatologię, aż po informatykę. Badaczy proszono o udzielenie odpowiedzi na zestaw dziewięciu pytań, w tym np. jaki typ danych tworzą, w jaki sposób te dane przechowują, czy je udostępniają oraz czy wiedzą i są zainteresowani tematyką długoterminowego przechowywania danych. Następnie dokonano jakościowej analizy zgromadzonego materiału poprzez grupowanie zbliżonych tematycznie odpowiedzi na tablicy. Odnalezione cechy wspólne utworzyły podstawę pod wykreowanie ośmiu person odzwierciedlających gamę postaw i potrzeb naukowców.

Autorzy ci mają świadomość, iż stworzone przez nich osobowości nie reprezentują całej populacji naukowców odwiedzających biblioteki akademickie (Lage et al., 2011, 921). Są jednak zdania, że persony zidentyfikowane w trakcie przeprowadzonych badań mogą zostać z powodzeniem wykorzystane przez inne instytucje zajmujące się inicjatywami związanymi z długoterminowym przechowywaniem danych. Lage wraz z Losoff i Maness $(2011,932)$ podkreślają, że wartość przeprowadzonych badań zawiera się właśnie w wyrażanych przez użytkowników spostrzeżeniach, które mogą być punktem wyjścia dla kolejnych badań pogłębiających analizowaną tematykę.

\subsection{Biblioteka Uniwersytetu Cornella w Ithace (USA)}

Pracownicy Biblioteki Uniwersytetu Cornella z pomocą konsultanta z TKG Consulting LLC posłużyli się metodą person w trakcie badań mających na celu odświeżenie wizerunku biblioteki poprzez nakierowanie usług na potrzeby użytkowników (Koltay \& Tancheva, 2008). Stworzone osobowości zostały wykorzystane nie tylko w pierwszej (wizualnej) fazie projektowania nowej bibliotecznej witryny internetowej, ale były także pomocne przy wyborze najtrafniejszych rozwiązań technicznych tworzonego serwisu.

Bazę pod budowę dziesięciu person (czworo pracowników uniwersytetu, troje magistrantów oraz troje studentów studiów pierwszego stopnia) stanowiło 36 około 30 minutowych rejestrowanych wywiadów (Cornell Univeristy, 2007). Zgromadzony materiał, poddany następnie analizie i syntezie, objął studentów i pracowników dziesięciu obszarów badawczych:

(1) Rolnictwa i Nauk o Życiu

(2) Architektury, Sztuki i Planowania 
(3) Sztuki i Nauki

(4) Inżynierii i Informatyki

(5) Hotelarstwa

(6) Ekologii człowieka

(7) Przemysłu oraz stosunków pomiędzy pracodawcą i pracownikami

(8) Prawa

(9) Weterynarii i Zootechniki

(10) Medycyny

Odnotowane charakterystyki oprócz podstawowych danych socjodemograficznych oraz informacji o preferowanych polach badawczych, zawierały również informacje o ulubionych miejscach pracy, stylach wyszukiwania, a także problemach czy propozycjach udoskonalenia bibliotecznego serwisu.

Koltay i Tancheva (2010) twierdzą, że persony mogą być efektywnym sposobem na uwzględnienie potrzeb użytkowników jeszcze na etapie planowania projektu. Usprawniają one komunikację wewnątrz zespołu, jak również wzbudzają empatię, ułatwiając zrozumienie zachowań i potrzeb użytkowników biblioteki akademickiej.

\subsection{Biblioteka Uniwersytetu Macquarie w Sydney (Australia)}

Z metody fikcyjnych osobowości skorzystali także pracownicy biblioteki Uniwersytetu Macquarie, w projekcie gruntownej przebudowy bibliotecznej strony WWW (Kennedy, 2008). Głównym celem tych badań było uchwycenie specyfiki użytkowników tej biblioteki, w szczególności ich potrzeb w zakresie korzystania z bibliotecznej strony WWW.

Zdecydowano, że witryna zostanie zrekonstruowana w oparciu o dwa filary - krytyczną ocenę eksperta oraz zidentyfikowane w badaniach potrzeby użytkowników. W badaniach użytkowników wykorzystano szereg technik, w tym: wywiady z pracownikami oraz z użytkownikami, grupy fokusowe, analizę stron internetowych, testy użyteczności i obserwacji (Kennedy, 2008). Warto zaznaczyć, że w trakcie typowania potencjalnych użytkowników witryny biblioteki zrezygnowano z kadry obsługującej charakteryzowaną placówkę - potrzeby informacyjne bibliotekarzy nie korespondują z potrzebami większości osób o słabym doświadczeniu w użytkowaniu systemów informacyjnych.

Dane zebrane $\mathrm{w}$ trakcie badań oraz analiza corocznych raportów bibliotecznych pozwoliły badaczom na zestawienie częstotliwości korzystania z bibliotecznych zasobów z doświadczeniem posiadanym przez danego użytkownika i tym samym wyróżnienie pięciu grup użytkowników:

(1) Rekreacyjni użytkownicy

(2) Sporadyczni użytkownicy

(3) Początkujący studenci

(4) Pilni studenci

(5) Doświadczeni badacze

W odniesieniu do powyższego podziału wykreowano pięć person oraz zaproponowano stworzenie jednej „antypersony” (odwzorowującej potrzeby bibliotekarzy), która wytyczyłaby granice projektowanych rozwiązań.

Kennedy (2008) podkreśla fakt, iż najważniejszym celem person jest pomoc w podejmowaniu decyzji dotyczących tworzonego projektu. Fikcyjne osobowości pozwoliły 
w opisywanym projekcie na stworzenie harmonogramu wprowadzania zmian na witrynie biblioteki poprzez hierarchizację odkrytych potrzeb. Persony zwróciły uwagę projektantów na pominięte obszary biblioteki i co więcej, pozwoliły na lepsze zrozumienie potrzeb użytkowników.

\section{Kontrowersje wokół metody person}

Wśród zalet płynących ze stosowania opisywanej metody podkreśla się jej skuteczność w uświadamianiu rzeczywistych potrzeb użytkowników, dla których zmienia się, modyfikuje lub planuje produkt - zaszczepiając ideę projektowania zorientowanego na użytkownika (Nielsen, 2013, 130). Metoda person ułatwia również podejmowanie decyzji, tzn. zamiast rozważać dziesiątki kombinacji, szuka się rozwiązania odpowiadającego celom konkretnej osobowości (Cooper, 2004, 170-171). Za stosowaniem person przemawiają także lepsze rozumienie klientów, krótsze cykle projektowania, ulepszona jakość produktu (Usability. gov, 2013).

Z kolei Rind $(2007,20)$ zwraca uwagę na to, że persony pozwalają skutecznie zhierarchizować pracę, w pierwszej kolejności skupiając ją na funkcjach, z których faktycznie skorzysta użytkownik.

Z drugiej strony, wartość person jest podważana ze względu na to, że prowadzi do zbytniego zawężania grupy odbiorców. Postrzegana jest też jako kolejna, nadmiarowa metoda wprowadzona do procesu projektowania (Rind, 2007, 21). Krytyka tego podejścia odnosi się również do nadużywania person i traktowania ich jako swoistego panaceum, które zastępuje wszystkie inne wykorzystywane do tej pory metody badania użyteczności (Pruitt \& Grudin, 2003, 11). Lene Nielsen zaznacza, że poznawanie potrzeb użytkowników poprzez spotkania z rzeczywistymi osobami jest postrzegane jako bardziej trafne, niż odwoływanie się do fikcyjnych osobowości (Nielsen, 2013, 17). Przypomina jednocześnie, że charakterystyki poszczególnych person (zawierające z definicji elementy fikcji) nie są ponadto metodą dającą powtarzalny efekt - nie mogą, zatem pretendować do miana metody naukowej (Nielsen, 2013, 17).

Choć persony mogą zdawać się nowością w świecie bibliologii i informatologii, to próby przeszczepienia opisywanej koncepcji na grunt tej dziedziny można odnaleźć już w publikacjach z 2007 i 2008 roku (Cornell Univeristy, 2007; Kennedy, 2008; Maness et al., 2008). Według Kathryn Lage, Barbary Losoffa i Jacka Mannesa (Lage et al., 2011, 919) metoda person była często wykorzystywana przy budowie bibliotecznych witryn internetowych. Za upowszechnianiem się opisywanej metody może także przemawiać fakt, iż jeden z felietonów Aarona Schmidta $(2012,19)$, autora cyklu publikacji taktujących o doświadczeniu użytkownika (ang. user experience) w „Library Journal”, poświęcony został właśnie usprawnianiu funkcjonalności biblioteki przy pomocy fikcyjnych osobowości.

Zmieniająca się infrastruktura informacyjna pociąga za sobą zmiany oczekiwań i potrzeb użytkowników, do których muszą dostosowywać się biblioteki i ich usługi informacyjne. Wykorzystanie w badaniu tych potrzeb nowych metod wypracowanych w innych naukach może - jak widać na przykładach opisanych w niniejszym artykule - zaowocować zapewnieniem większej funkcjonalności placówek bibliotecznych i lepszym dopasowaniem ich usług do potrzeb użytkowników. 


\section{Bibliografia}

Adlin, T.; Pruitt, J.; Goodwin, K.; Hynes, C.; McGrane, K.; Rosenstein, A.; Muller, M. J. (2006). Putting Personas to Work. In: Gulz, A. (eds.). CHI'06 Extended Abstracts on Human Factors in Computing Systems (CHI EA '06). New York: ACM Press, 13-16.

Casement, A. (2010). Persona. In: Leeming, D. A., Madden, K., Marlan, S. (eds.). Encyclopedia of Psychology and Religion. New York: Springer, 670-672.

Chang, Y.; Lim, Y.; Stolerman, E. (2008). Personas: From Theory to Practices. In: K. Tollmar (ed.). Proceedings of the 5th Nordic conference on Human-computer interaction: building bridges. New York: ACM, 439-442.

Cooper (2013). Cooper [online]. Cooper, [23.01.2017], http://www.cooper.com

Cooper, A. (2004). The Inmates Are Running the Asylum. Indianapolis: SAMS.

Cooper Interaction Design (1996). Why I Am Called "the Father of Visual Basic." [online]. Cooper Interaction Design, [23.01.2017], http://www.cooper.com/alan/father_of_vb.html

Cornell Univeristy (2007). The Cornell University Library Personas [online].Cornell University, [23.01.2017], http://hdl.handle.net/1813/8302

Digital native. (2014). In: Oxford Dictionaries [online]. Oxford University Press [23.01.2017], http:// en.oxforddictionaries.com/definition/digital_native

Djajadiningrat, J. P.; Gaver, W. W.; Fres, J. W. (2000). Interaction Relabelling and Extreme Characters: Methods for Exploring Aesthetic Interactions. In: D. Boyarski, W. A. Kellogg (eds.) Proceedings of the 3rd Conference on Designing Interactive Systems: Processes, Practices, Methods, and Techniques (DIS '00). New York: ACM Press, 66-71.

Floyd, I.; Jones, M. C.; Twidale, M. (2008). Resolving Incommensurable Debates : A Preliminary Identification of Persona Kinds, Attributes, and Properties. Artifact [online], 2(1), [ 23.01.2017], http://scholarworks.iu.edu/journals/index.php/artifact/article/view/3912

Högskolan i Borås (2014a). Borås Academic Digital Archive (BADA) [online]. Högskolan i Borås, [23.01.2017], http://bada.hb.se

Högskolan i Borås (2014b). University of Boras: Ping Pong [online]. Högskolan i Borås, [23.01.2017], https://pingpong.hb.se/login/processlogin?targeturl=\%2FstartPage.do

Interaction Design Association (2014). IxDA Mission [online]. Interaction Design Association, [23.01.2017], http://web.archive.org/web/20160608125807/http://ixda.org/about/ixda-mission

Kennedy, P. (2008). Audience Personas for the Macquarie University Library Website [online]. Step Two Designs Pty Ltd, [23.01.2017], http://www.steptwo.com.au/papers/kmc_macquariecasestudy/ index.html

Koltay, Z.; Tancheva, K. (2008). Personas and a User-Centered Visioning Process. Library Assessment Conference: Building Effective, Sustainable, Practical Assessment, Seattle, Washington, August 4-7, 2008 [online]. Cornell University Library, [23.01.2017], http://libraryassessment.org/bm doc/ koltay.pps

Koltay, Z.; Tancheva, K. (2010). Personas and a User-Centered Visioning Process. Performance Measurement and Metrics [online], 11(2), 172-183, [23.01.2017], http://www.emeraldinsight.com/ doi/abs/10.1108/14678041011064089

Lage, K.; Losoff, B.; Maness, J. (2011). Receptivity to Library Involvement in Scientific Data Curation: A Case Study at the University of Colorado Boulder. Portal: Libraries and the Academy [online], 11(4), 915-937, [23.01.2017], https://doi.org/10.1353/pla.2011.0049

LaGuardia, C. (1998). Recreating the Academic Library: Breaking Virtual Ground. New York: Neal Schuman Publishers.

Maness, J. M.; Miaskiewicz, T.; Sumner, T. (2008). Using Personas to Understand the Needs and Goals of Institutional Repositories. D-Lib Magazine [online], 14(9/10), [23.01.2017], http://www. dlib.org/dlib/september08/maness/09maness.html 
Nielsen, L. (2013). Personas - User Focused Design. London: Springer.

Norman, D. (2004). Ad-Hoc Personas E Empathetic Focus [online]. jnd.org, [23.01.2017], http://www. jnd.org/dn.mss/personas_empath.html

Plezia, M. (red.). (1999). Stownik łacińsko-polski. T. 4. Warszawa: Wydawnictwo Naukowe PWN.

Pruitt, J.; Grudin, J. (2003). Personas: Practice and Theory. In: Proceedings of the 2003 conference on designing for user experiences (DUX '03). New York: ACM Press.

Rind, B. (2007). The Power of the Persona. The Pragmatic Marketer, 5(4), 18-22.

Schmidt, A. (2012). Persona Guidance. Library Journal, 137(16), 19.

Serials Solutions. (2012). The Summon Service [online]. Serials Solutions, [23.01.2017], http://www. proquest.com/products-services/The-Summon-Service.html

Sinha, R. (2003). Persona Development for Information-Rich Domains. In: CHI '03 Extended Abstracts on Human Factors in Computing Systems (CHI EA '03). New York: ACM Press, 830-831.

Usability.gov (2013) Develop Personas [online]. U.S. Department of Health \& Human Services, [23.01.2017], https://web.archive.org/web/20130208181401/http://www.usability.gov/methods/ analyze_current/personas.html\#.WIXgMvnhBp8

\section{Załącznik \\ Persony stworzone przez pracowników Library and Learning Resources w Szkole Wyższej w Borås ${ }^{10}$}

\section{Persona 1: Hedwig}

Wiek: 28 lat

Wykształcenie: projektantka mody, 2 rok studiów

Wszystkie popularne magazyny, które kosztuja

okoto 100 koron powinny się znajdować w bibliotece.

Hedwig urodziła się w 1982 roku w miejscowości Kävlinge, znajdującej się w obrębie regionu Skåne. Rodzice Hedwig pracowali na uczelni na kierunkach związanych ze sztuką i od samego początku było jasne, że Hedwig nie skończy edukacji na poziomie liceum, a będzie ją kontynuować na studiach. Po szkole średniej zdecydowała się zostać najbardziej znanym projektantem mody na świecie. W tym celu wiele razy spotykała się ze swoim doradcą zawodowym, żeby razem zdecydować, jaką drogę powinna obrać, aby osiągnąć zamierzony cel. Bardzo wcześnie uzmysłowiła sobie, że dobre oceny z lekcji techniki to zbyt mało, dlatego uczestniczyła również w kursach szycia ubrań - wieczorami, w czasie nauki w szkole średniej. Bezpośrednio po ukończeniu szkoły, Hedwig zapisała się na kursy przygotowawcze do studiów, odbywające się w miejscowości Steneby. Były to dwa jednoroczne kursy: materiałoznawstwa oraz kurs ze specjalizacją wykorzystania skóry i futra w przemyśle tekstylnym. Następnie, Hedwig razem ze znajomą postanowiła zamieszkać przez rok w Londynie. Udało

10 Dzięki uprzejmości i za zgodą Martina Borga, autor mógł - z pomocą rodzimego użytkownika języka szwedzkiego - przetłumaczyć i załączyć niniejsze materiały źródłowe, oznaczone numerami od 1 do 4 . 
jej się znaleźć pracę w znanym domu mody, w którym pracowała rok zanim postanowiła zrobić następny krok na ścieżce swojej edukacji, czyli rozpocząć studia w Danii. Dostała się do Akademii Krawieckiej w Kopenhadze, gdzie studiowała krawiectwo damskie i męskie oraz ukończyła kurs projektowania i szycia kostiumów filmowych, teatralnych i baletowych.

Kiedy Hedwig dostała się na THS ${ }^{11}$ spełniło się jej marzenie. Pokochała studiowanie, a także czuła, że zaczęła rozwijać swoje talenty w wymarzonej profesji. Jej cel, żeby zostać znanym na całym świecie projektantem mody jest nadal aktualny. Większą część swojego czasu spędza na samodzielnej pracy, tworząc szkice i plany ubrań, przy dużym stole kreślarskim w lokalach szkoły przy ulicy Bryggare. Parę razy w semestrze Hedwig wybiera się do biblioteki, głównie po to, żeby znaleźć inspirację do zadań, które otrzymała od swojego nauczyciela. Przechadza się zwykle między półkami na drugim piętrze, przeglądając książki z dziedzin nauk przyrodniczych. Hedwig jest przekonana, że okładki tych książek często są bardzo dobrze przemyślane i zaprojektowane z wykorzystaniem pięknych motywów. $\mathrm{Z}$ tego powodu, często kopiuje ich okładki i gromadzi je w swoim portfolio, żeby móc je ewentualnie wykorzystać w przyszłości. Hedwig pochwala fakt, iż w bibliotece jest tyle inspirującej literatury - zarówno książek jak i czasopism. Za każdym razem rzuca się na najnowsze wydanie Dazed \& Confused, poszukując natchnienia. Kiedy w zeszłym miesiącu zobaczyła duży album domu mody Gucii, była tak pozytywnie zszokowana, że od razu usiadła na podłodze między regałami i zaczęła czytać. Hedwig nie wyszła stamtąd, dopóki nie zauważyła, jak bardzo zgłodniała.

Cele:

- w bibliotecznych zbiorach znajduje się dużo literatury o inspirującym charakterze,

- książki i czasopisma są prezentowane w inspirujący sposób,

- w bibliotece istnieje możliwość wypicia filiżanki kawy i zjedzenia bułki, a zarazem czytania w relaksującym otoczeniu z wygodnymi fotelami,

- w bibliotece istnieje możliwość kopiowania, drukowania i skanowania w kolorze oraz wysokiej jakości.

\section{Persona 2: Lisa}

Wiek: 26 lat

Wykształcenie: bibliotekarka, 3 rok studiów

Odwiedzanie biblioteki czasami tudzaco przypomina pójście do pracy.

Lisa urodziła się w miejscowości Vetlanda w 1984 roku. Podczas nauki w szkole średniej, w klasie nauk społecznych, zdała sobie sprawę, że chce wyjść na świat i się rozejrzeć. Zaraz po szkole średniej, wyjechała do Genewy w Szwajcarii, żeby pracować przez rok, jako opiekunka dziecięca i w tym samym czasie podszlifować swój francuski - studiując jeden semestr na tamtejszym uniwersytecie.

Po powrocie z Genewy, Lisa chciała studiować dalej. Dostała się na uczelnię w Göteborgu, gdzie studiowała literaturoznawstwo, a następnie zdecydowała się na zmianę swojej ścieżki kariery na bibliotekarstwo. Dzieli mieszkanie z przyjaciółką.

${ }^{11}$ The Swedish School of Textiles - jeden z wydziałów Szkoły Wyższej w Borås. 
Lisa regularnie odwiedza bibliotekę. Nie lubi zbytnio uczyć się w domu. Najbardziej jej się podoba, że tak łatwo jest dostać się do biblioteki oraz udostępnionych komputerów, żeby sprawdzić swojego maila czy odświeżyć swój status na Facebooku.

Ponieważ Lisa najchętniej pracuje na swoim laptopie, z tego powodu nie korzysta z sal komputerowych i najchętniej przesiaduje na czwartym piętrze biblioteki. Jest tam spokojniej, niż na trzecim czy na drugim piętrze, a poza tym książki z dziedzin bibliotekoznawstwa i informacji naukowej są na wyciągnięcie ręki. Doskwiera jej zakaz wnoszenia ze sobą kubka kawy do biblioteki. Jest przekonana, że myśli jej się lepiej, jeśli ma w pobliżu filiżankę kawy. Czasami marzy jej się cicha sala komputerowa, w której mogłaby studiować bez rozpraszających dźwięków, w ciszy. Jak na razie, jest zmuszona uciekać się do słuchawek i muzycznego serwisu Spotify, żeby odizolować się od otoczenia.

Lisa jest ambitna i chce ukończyć swoje studia w terminie. Jej celem jest praca w bibliotece naukowej lub uniwersyteckiej. Chce napisać swoją pracę licencjacką poruszając zagadnienia kompetencji informacyjnych w kontekście szwedzkich uniwersytetów.

Lisa zdaje sobie sprawę, że w bibliotece uniwersyteckiej znajdują się użyteczne zasoby, zarówno w postaci fizycznej jak i elektronicznej. Niezbyt chętnie prosi o pomoc bibliotekarza stojącego w punkcie informacyjnym, ponieważ uważa, że sama powinna dać sobie radę, zważywszy na to, jak daleko już zaszła w swoich studiach. Lisa w ogóle rzadko prosiła o pomoc w punktach informacyjnych. $Z$ drugiej strony, bardzo docenia pomoc techniczną i często z niej korzysta - zwłaszcza, jeśli ma problem z drukowaniem lub kopiowaniem, co się bardzo często jej się zdarza. Lisa uważa, że usytuowanie pomocy w bezpośrednim sąsiedztwie wejścia do biblioteki jest świetnym pomysłem.

Cele:

- chciałaby mieć dostęp do różnego typu miejsc pracy, najchętniej cichej sali komputerowej,

- chciałaby móc załatwiać różnorodne sprawy; wypożyczać i oddawać książki, sprawdzać e-mail, drukować itd.,

- chciałaby studiować w przytulnej atmosferze bibliotecznej,

- chciałaby szybko ukończyć studia, żeby móc ubiegać się o pracę w bibliotece naukowej.

\section{Persona 3: Reza}

Wiek: 21 lat

Wykształcenie: inżynier-mechanik, 1 rok studiów Jeśli jest nas więcej, to te kwadratowe stoły sq odpowiednie wystarczy miejsca na wiele rzeczy: kalkulator, tabelki i dokumenty.

Reza urodził się w 1989 w Borås. Jego rodzice pochodzą z Iranu. Przyjechali do Szwecji na początku lat 80-tych. Ponieważ ojciec Rezy jest inżynierem, a jego matka pielęgniarką oboje wykształceni w ojczyźnie - Reza został zainspirowany przez nich do studiowania na uniwersytecie. Technika i maszyny interesowały Rezę od czasów jego dzieciństwa. W szkole średniej imienia Svena Ericssona, Reza uczęszczał do klasy o profilu technicznym. Był to dla niego naturalny wybór i zakończył swoją edukację z dobrymi ocenami. Zanim Reza 
zaczął ubiegać się o przyjęcie na uniwersytet, przejrzał katalogi edukacyjne wielu szkół wyższych. Najbardziej zainteresowała go szkoła Chalmers oraz $\mathrm{KTH}^{12}$, ale jego oceny nie spełniły wymogów rekrutacyjnych. Został jednakże przyjęty na kierunek inżyniera-mechanika w Szkole Wyższej w Borås.

Dla Rezy studia są ważne, ale odkrył również, że w ich trakcie nie wolno rezygnować z dobrej zabawy. Reza nawiązał wiele nowych kontaktów, lubi spędzać czas na dworze i chodzić na imprezy. Z tego powodu może się okazać, że ukończenie studiów będzie wymagać od Rezy nauki semestr dłużej, ale nie jest to dla niego szczególnie istotne, ponieważ tanie mieszkanie i możliwość dodatkowej pracy sprawia, że jakoś wiąże koniec z końcem. Po obronie pracy inżynierskiej, Reza zamierza studiować dalej i być może połączyć zatrudnienie w jakiejś firmie ze studiami doktoranckimi.

Biblioteka uczelni jest bardzo często odwiedzana przez Rezę i jego kolegów. Razem chętnie pracują przy stolikach na otwartych piętrach biblioteki. Pomimo że, korzystają czasem z pokoi grupowych, nie traktują ich priorytetowo - ich styl pracy wymaga większej ilości komputerów, niż istniejącym wyposażeniu wspomnianych pokoi. Dlatego praca w sali komputerowej, gdzie kilka osób w grupie może używać komputerów jednocześnie, bardziej odpowiada Rezie i jego kolegom. Nie przeszkadza im zbytnio gwar rozmów, ani obecność innych grup. W trakcie intensywnej pracy grupowej, Reza i jego znajomi mają wiele komputerów włączonych w tym samym czasie, porozkładane książki i notatniki na stole, a na dodatek, chętnie wypiliby kawę, żeby uzupełnić zapasy energii. Dobrze funkcjonujące wyposażenie techniczne, a najlepiej komputery z dużymi ekranami oraz oprogramowanie, które może być używane niezależnie od sprzętu jest dla nich istotną kwestią, jak również łatwość obsługi systemu do drukowania i kopiowania. Na kierunku dla inżynierów-mechaników ćwiczenia są dominującym sposobem pracy. Dlatego też, nie korzysta się tam z dużej ilości obowiązkowych podręczników. Z tego powodu, Reza nie wypożycza zbyt wielu książek. Używane przez niego, od czasu do czasu, stacje do samodzielnego wypożyczania zwykle działają dobrze. Dział czasopism również nie jest przez niego zbyt często odwiedzany, bo większość potrzebnych materiałów, Reza znajduje w elektronicznych zasobach biblioteki.

Cele:

- w bibliotece powinny znajdować się obszerne stanowiska, żeby ułatwić pracę grupową,

- specjalistyczne oprogramowanie, które jest niezbędne w edukacji Rezy, powinno być dostępne na bibliotecznych komputerach,

- liczba komputerów wystarczająca do równoczesnej i wspólnej pracy w grupie,

- powinna istnieć możliwość wypicia kawy razem z przyjaciółmi podczas studiowania,

- łatwy dostęp do konta druku, np. poprzez Internet.

\footnotetext{
${ }^{12}$ KTH Royal Institute of Technology - największy oraz najstarszy uniwersytet techniczny w Szwecji.
} 


\title{
Persona 4: Teresa
}

\author{
Wiek: 32 lat \\ Wykształcenie: pedagog, 2 rok studiów \\ Wyobraź sobie, że można byłoby mieć projektor w pokoju grupowym tak, \\ aby wszyscy równocześnie mogli zobaczyć, co ktoś pisze na komputerze.
}

Teresa urodziła się w 1978 w Borås. Od zawsze kochała dzieci, dlatego kiedy przyszedł czas wyboru profilu klasy, bez wahania zdecydowała się na nazywany: „dziecko i czas wolny”, w szkole w Almas. Oczywistością był fakt, że Teresa będzie pracować z dziećmi, a ponieważ nigdy nie lubiła się uczyć, szczęśliwie się złożyło, że jej edukacja będzie trwała tylko 2 lata. Po liceum zaczęła pracować $\mathrm{z}$ najmłodszymi, jako asystentka w przedszkolu na obrzeżach Borås. Bardzo jej się tam podobało i czuła, że ta praca dużo jej dała. Kiedy Teresa miała 23 lata, urodziła nareszcie własne dziecko - Tindrę i starała się wydłużyć czas zwolnienia macierzyńskiego, jak tylko mogła. Kiedy wróciła do zawodu, zaczęła pracować na 3/4 etatu. Razem z dorastająca Tindrą, zmieniły się potrzeby jej mamy - nie jest już zachwycona posadą asystentki, chce czegoś więcej, ale jeszcze nie wie dokładnie czego. Kiedy Tindra zaczęła chodzić do zerówki, Teresa zdała sobie sprawę, w jaki sposób mogłaby osiągnąć bardziej zadowalające życie profesjonalne, zdecydowała się zostać nauczycielką. Teresa decyduje się na przerwę w pracy i rozpoczyna naukę na kierunku pedagogiki w Szkole Wyższej w Borås.

Ponieważ Teresa opiekuje się rodziną i dzieckiem, chce zakończyć studia tak szybko i na tyle bezboleśnie, jak to tylko możliwe. Wie, czego chce i postrzega swoje studia, jako pracę, która ma ją poprowadzić do bardziej satysfakcjonującej codzienności zaraz po graduacji. Chcąc pogodzić obowiązki rodzinne ze studiami, Teresa stara się wykonać większość obowiązkowych zadań w czasie pobytu na uczelni. Kiedy nie ma wykładów, większość czasu spędza w bibliotece na pracy grupowej, zajmując się różnymi projektami. Zespoły często składają się z 6 do 10 osób i najchętniej pracują w pokojach grupowych, gdzie nikt im i zarazem, oni nikomu nie przeszkadzają. Nierzadko zdarza się, że w trakcie całodniowej pracy, chętnie zjedliby kanapkę i napili się kawy, bez robienia specjalnych przerw na jedzenie poza budynkiem biblioteki. Teresa ma długie listy lektur i najchętniej całą obowiązkową literaturę wypożyczałaby w uczelnianej bibliotece. Byłoby najlepiej, gdyby potrzebne jej książki znajdowały się wszystkie w jednym miejscu, ale to jest „ok”, że wszystkie podręczniki ulokowane są w piwnicy nawet, jeśli czasami trudno jest zrozumieć, w jaki sposób zostały ustawione na półkach. Często zdarza się, że nie potrzebuje wypożyczać całych pozycji, a zależy jej jedynie na skopiowaniu poszczególnych rozdziałów. W takich momentach, przydałyby się łatwe do zrozumienia instrukcje obsługi kopiarek, a także, w razie potrzeby, jakaś pomoc. Najważniejsze, żeby maszyny do wypożyczania i zwracania książek były łatwe do znalezienia oraz proste w obsłudze.

Cele:

- chciałaby wykonywać zadane prace w ciągu dnia tak, aby uzyskać dodatkowy czas wieczorami dla rodziny,

- chciałaby mieć dostęp do pokojów grupowych i miejsca zaprojektowanego z myślą o współpracy z innymi studentami,

- aby unikać przerywania pracy, powinna istnieć możliwość zjedzenia kanapki i wypicia kawy w pokoju grupowym, 
- chciałaby mieć dostęp do sprawnych technicznie urządzeń, a także pomocy w ich obsłudze,

- chciałaby w łatwy sposób znajdować podręczniki,

- chciałaby bez problemów odnajdować i korzystać z maszyn do wypożyczania i zwracania książek.

\title{
The Personas Method in Designing University Library Services
}

\begin{abstract}
Purpose/Thesis: The aim of this paper is to introduce a new approach to the identification of library users' needs on the grounds of so-called personas method.

Approach/Methods: The critical analysis of the literature and source materials obtained from Högskolan i Borås (University of Borås) library employee provide the background for this paper. The use of person method in designing library services is exemplified by four case studies: University Library in Borås (Sweden), University of Colorado at Boulder faculty libraries (USA), Cornell University Library in Ithaca (USA), Macquarie University Library in Sydney (Australia).

Results and conclusions: Person method, based on human-computer interaction, was described. The analysis of the examples described in this work confirmed that the application of methods developed in other disciplines may result in improved library functionality as well as better adjustment of library services to their users' needs.

Originality/Value: This paper proposes a new approach to the identification of users' needs, the approach not present so far in Polish literature.
\end{abstract}

\section{Keywords}

University libraries. Information users. Personas Method. User profiles. User studies.

Mgr JAKUB OPAS jest absolwentem studiów drugiego stopnia (2015) na kierunku Informacja Naukowa i Bibliotekoznawstwo w Instytucie Informacji Naukowej i Studiów Bibliologicznych Uniwersytetu Warszawskiego. Obecnie pracuje w agencji reklamowej Cheil Poland jako kierownik dziatu centrum ustug wspólnych.

Kontakt $z$ autorem:

jakub.opas@gmail.com 